\title{
Hydrologic and microclimate characterizations of Thornton's Cave, West-Central Florida (USA)
}

\author{
Dorien K. McGEE \\ ExxonMobil Exploration Company, PO Box 4778, Houston, TX 77210-4778, USA
}

Received August 2011; accepted January 2012

Available online 6 February 2012

DOI: $10.5038 / 1937-8602.57 .1 .5$

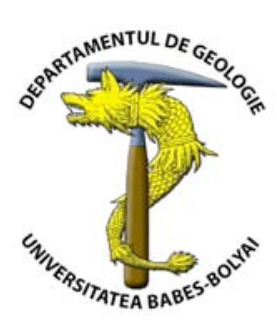

\begin{abstract}
A cave's subsurface environment is controlled by a suite of factors unique to the surrounding environment in which the cave formed, including, but not limited to, regional geologic, and climate settings. These factors collectively owe to wide variations in cave biology, geomorphology, and overall speleogenesis. This report combines local climate, hydro-logic, and $\mathrm{CO}_{2}$ data collected over the course of a two-year study at Thornton's Cave, a partially-flooded cave in the West-Central Florida karst belt, to characterize its current environment and yield insight regarding how changes in regional climate and hydrology impact its past and future speleogenesis. Data loggers continuously monitoring cave and surface air temperatures, water levels and surface rainfall documented immediate responses in the cave to long- and short-term fluctuations in these parameters at the surface. Atmospheric $\mathrm{CO}_{2}$ in the cave and at the surface demonstrate seasonal trends, though the cave maintains higher concentrations and lower $\delta^{13} \mathrm{C}_{\text {of }} \mathrm{CO}_{2}$ than the surface, suggesting decomposition of organic matter, and to a lesser degree macroorganisms are contributing proportionally more $\mathrm{CO}_{2}$ to the cave. Collectively, these interpretations provide insight on the impact of surface processes on cave formation here, and suggest that a biotic model of speleogenesis using bacterially-sourced $\mathrm{CO}_{2}$ as a component of dissolution may be possible. Further, they can be used to further the understanding of the karstification in West-Central Florida and analogous karst regions.
\end{abstract}

Key words: Cave, hydrology, karst, speleogenesis, microclimate, Thornton's Cave, Florida.

\section{INTRODUCTION}

Speleogenesis and the evolution of karst terrains are dictated by a variety of factors including the depositional and geologic history of the landscape, climate and sea-level fluctuation, and local hydrology (Palmer, 2007). These factors work in concert to drive the geomorphology of cave systems and their understanding is critical to determining other cave processes, specifically the relationship between rainfall and dissolution of calcium carbonate. The availability and flow of water through a cave system is considered the primary agent governing these processes by serving as a main vector of geochemical transport into and out of the cave. Air is another vector of geochemical transport, controlled by the degree of openness of the cave to the surface as well as surface climate, which drives the density and pressure contrasts that act to push air into and out of the cave. Surface climate also controls hydrologic patterns by governing hydrologic inputs and sea-level, which impact speleogenesis on a variety of time scales from the enlargement of existing caves to the deposition of sediments necessary to form the initial limestone settings which are then subjected to karstification and speleogenesis. Collectively, these processes establish the framework that governs the geochemical processes occurring in the cave such as limestone dissolution and organic matter decomposition. Here we explore the climate, hydrologic and carbon dioxide $\left(\mathrm{CO}_{2}\right)$ profiles (including $\mathrm{CO}_{2}$ production in cave substrates) of Thornton's Cave in West-Central Florida over a two-year period beginning in late March 2007. The data from this study were then used to create a basic understanding of how the cave environment is impacting speleogenesis.

\section{REGIONAL SETTING}

The karst region of West-Central Florida is part of a karst belt that extends from the Florida Panhandle to just south of Tampa Bay (Fig. 1). Topographic highs in this region are dominated by the Brooksville Ridge and the larger Ocala Platform, which serve as regional boundaries for the Withlacoochee River basin. Surface stratigraphy is dominated by Middle Eocene to Late Oligocene limestones comprising the Avon Park Formation as well as the Ocala and Suwannee Limestones (Fig. 2). In the Brooksville Ridge and Ocala areas, the uppermost portion of the Ocala Limestone, and in places, the Suwannee Limestone, were eroded during the Oligocene, followed by infilling of sinks and solution pits of the remaining Ocala Limestone with Miocene and younger sediments (Yon and Hendry, 1992). As a result, the highly porous Ocala Limestone $(\sim 35 \%$ total $)$ is the primary unit containing the Floridan Aquifer in WestCentral Florida, with active circulation of groundwater contributing to the region's karstification (see Stringfield and LeGrand, 1966; Lane, 1986). With the exception of the Withlacoochee River, surface streams are precluded and the majority of surface waters exist as springs, sinkhole ponds, and wetlands adjacent to the river. 


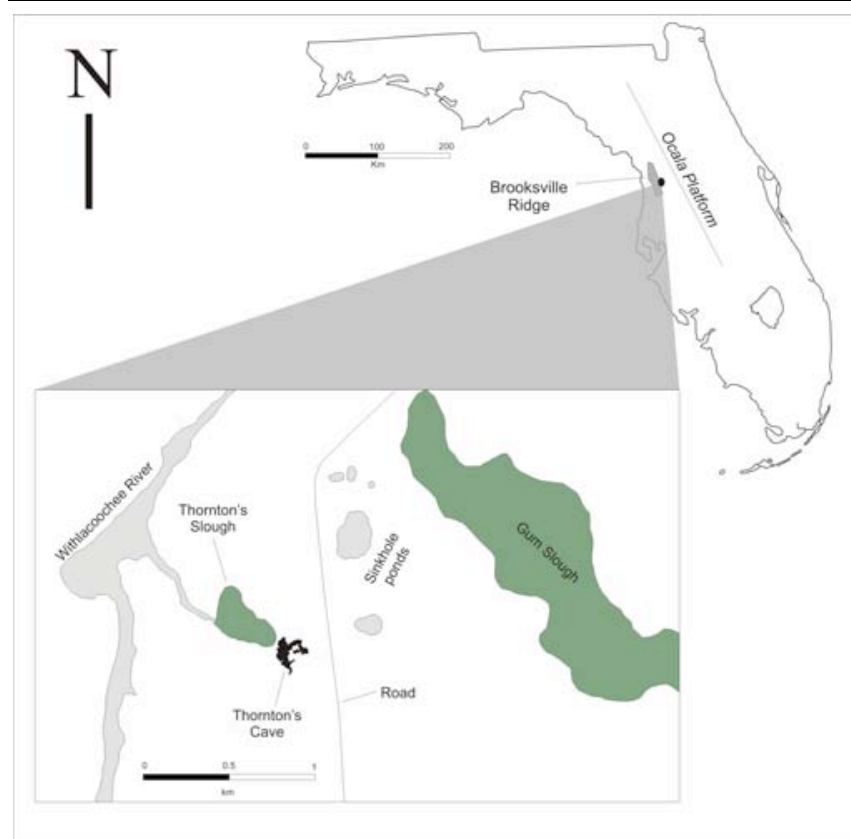

Fig. 1. Regional map of Thornton's Cave area.

\begin{tabular}{|c|c|c|}
\hline System & Series & Lithostratigraphy \\
\hline Quaternary & $\begin{array}{l}\text { Holocene } \\
\text { and } \\
\text { Pleistocene }\end{array}$ & Alluvium \\
\hline \multirow{8}{*}{ Tertiary } & Pliocene & $\begin{array}{c}\text { Undifferentiated Deposits } \\
\text { (Caloosahatchee Mart and } \\
\text { Bone Valley, Alachua, \& Tamiam } \\
\text { Formations) }\end{array}$ \\
\hline & \multirow{2}{*}{ Miocene } & Hawthorne Formation \\
\hline & & Tampa Limestone \\
\hline & Oligocene & Suwannee Limestone \\
\hline & \multirow{3}{*}{ Eocene } & Ocala Limestone \\
\hline & & Avon Park Formation \\
\hline & & Oldsmar Formation \\
\hline & Paleocene & Cedar Keys Formation \\
\hline
\end{tabular}

Fig. 2. Stratigraphy of West-Central Florida (adapted from Miller, 1984; Randazzo, 1997).

Wet and dry caves of various sizes and morphologies occur throughout West-Central Florida (including submerged caves on the West Florida Shelf) and are largely aligned with marine terraces formed during sea-level highand lowstands, indicating their formation was driven by glacioeustatic sea-level fluctuation (Florea et al., 2007). Local variations in lithology and the position of the groundwater table, however, are believed to exert a minor control on speleogenesis as well. In particular, Florea et al. (2007) hypothesized that recharge to the Floridan Aquifer by the Withlacoochee River combined with reduced permeability from riverine sediment infilling the pore space of the underlying limestone may locally raise the groundwater table. As a result, dissolution in association with Plio-Pleistocene sea-level fluctuation is reactivated, allowing speleogenesis of caves in this area to occur over multiple generations.

\section{THORNTON'S CAVE}

Thornton's Cave is in western Sumter County, Florida, less than $1 \mathrm{~km}$ east of the Withlacoochee River on privately owned land (Figs. 1,3). Between the cave and the river is an open, seasonally flooded wet prairie (Thornton's Slough) fed directly by the river, and a narrow cypress stand. The cave is $\sim 14.4 \mathrm{~m}$ above mean sea-level within the Ocala Limestone and intersects the unconfined Upper Floridan Aquifer such that some passages are flooded throughout the year. The alignment of Thornton's Cave with the Talbott marine terrace (paleoshoreline) suggests the primary control on its formation was sea-level; however, local elevation of the groundwater table exerted by the Withlacoochee River is thought to issue a modern control, promoting further dissolution of the cave beyond that of other caves in the West-Central Florida region that are at similar elevations but farther from the river (Cook 1931, 1945; Florea et al., 2007).

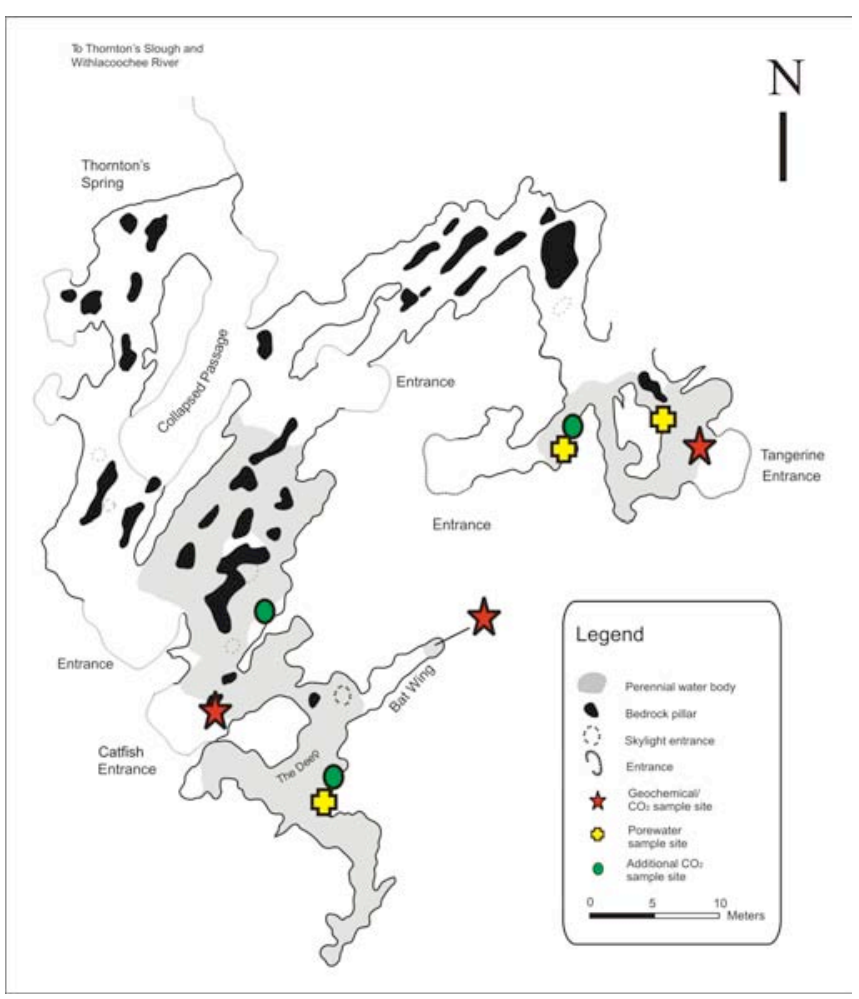

Fig. 3. Thornton's Cave map (modified from Florea et al., 2006).

Approximately $315 \mathrm{~m}$ of the cave's dry passages have been mapped, while submerged passages remain relatively unmapped. Exploratory dives in the Tangerine Entrance documented a submerged vertical passage extending into the aquifer beyond $35 \mathrm{~m}$ in depth, suggesting this area of the cave may function as a spring for at least part of the year. Periodic flooding of dry passages (and rising water-level in the flooded passages) occurs during the summer wet season, while high permeability and transmissivity measurements of the Ocala Limestone in this region (approximately $10^{-12}$ to $10^{-13} \mathrm{~m}^{2}$ and 23,225 to $46,450 \mathrm{~m}^{2} /$ day, respectively) support rapid recharge of the aquifer and therefore rapid response to surface rain events (Ryder, 1985; Budd and Vacher, 2004; Florea, 2006). The cave is also hypothesized to facilitate the 
transport of water between Gum Slough $(<1 \mathrm{~km}$ to the west) and the Withlacoochee River (Florea et al., 2006). When the water-level at Gum Slough is higher than the river, water is believed to drain westward through the cave and out from Thornton's Spring, through the cypress stand and Thornton's Slough toward the river, with the opposite effect occurring when the river level is higher; however, periodic droughts combined with increasing regional withdrawal on the aquifer for agricultural and development purposes appear to periodically restrict westward flow from Gum Slough (Ryder, 1985).

Collapse features and solution pits are exceptionally common at the cave due to its shallow position, just $1.7 \mathrm{~m}$ below the land surface. No fewer than 26 entrances, eight of human size, are present, subjecting the cave to year-round infilling of sediment and organic matter and rainfall from the surface. The cave also serves as a maternity roost for a breeding bat colony, typically along the Bat Wing (Fig. 3), containing several thousand individuals from approximately late April to mid-August.

\section{METHODS}

To establish a record of climate, hydrology, and $\mathrm{CO}_{2}$ for this site, continual monitoring of these parameters took place over a two-year period from 2008 to 2010 both at various points within the cave, and at its surface. Temperature, rainfall, and water-levels were monitored using dataloggers (discussed below), while $\mathrm{CO}_{2}$ concentration and $\delta^{13} \mathrm{C}$ values were monitored twice annually in the summer and winter by collecting atmospheric gas samples in the cave and at the surface. Fluctuations in $\mathrm{CO}_{2}$ concentration and $\delta^{13} \mathrm{C}$ values were of particular importance in estimating the contribution of biogenic $\mathrm{CO}_{2}$, exhibited by ${ }^{13} \mathrm{C}$-depleted $\mathrm{CO}_{2}$ to the cave atmosphere (e.g., Craig, 1953; Ehleringer et al., 2000). Further, bench-top experiments sampling $\mathrm{CO}_{2}$ produced and respired from cave substrates and sediments and surface soils were conducted to more specifically determine the potential for heterotrophic microorganisms to contribute to cave atmospheric $\mathrm{CO}_{2}$ profiles. Collectively, these data were used to establish a working knowledge of the subterranean environment of Thornton's Cave and its relationship to local hydrologic patterns and climate. These data were also compiled with geochemical data in separate studies investigating biogenic models for speleogenesis and related microbiotic activity at this cave. The results of these studies are discussed in McGee (2010) and Florea et al. (2011).

\section{Climate and hydrologic monitoring}

Air temperature was monitored at the surface and inside the cave over the two-year monitoring period. Air temperature was continuously monitored at ten minute intervals at the surface using a Gemini Tinytag Plus 2 temperature datalogger (model TGP-4500, accuracy $\pm 3.0 \%$ ) in a tree away from direct sunlight $\sim 3 \mathrm{~m}$ from the Tangerine Entrance. Cave-air temperatures were continually monitored just inside the Catfish Entrance and in The Deep ( $\sim 5 \mathrm{~m}$ southwest from the entrance to the Bat Wing passage) using Onset pendent temperature dataloggers (HOBO model UA-002-064, accuracy $\left.\pm 0.54^{\circ} \mathrm{C}\right)$. Water temperatures were monitored at The Deep (identical location as air temperature) using the same pendent datalogger at ten-minute intervals, and at the
Tangerine Entrance using a water-level/temperature logger (discussed below). Surface soil temperature was monitored from January 2009 to April 2010 by burying a HOBO temperature logger approximately $20 \mathrm{~cm}$ below the soil surface outside the Catfish Entrance.

Water-levels were measured hourly at the Tangerine Entrance using an Onset water-level logger (HOBO model U20-001-02, accuracy $=0.05 \%$ FS), which also collected the above-mentioned temperature data (also at hourly intervals). The water-level logger was calibrated by measuring the depth at a fixed point in the cave; however, due to uneven cave-floor topography, particularly along the northeastern wall of the Tangerine Entrance where divers descended into the aquifer, water-level data could be used to measure trends only and not actual water-level at that entrance. Water-level fluctuations at the Withlacoochee River were collected from the Pineola gauging station, approximately $5 \mathrm{~km}$ upstream from the cave. This station is part of the National Water Information System (NWIS station ID 02312598) and is jointly monitored by the United States Geological Survey (USGS) and the Southwest Florida Water Management District (SWFWMD). Approved waterlevel data reported for this station were daily averages downloaded from the NWIS web interface (NWIS, 2010). Rainfall was measured using a HOBO RG3-M tipping bucket gauge and datalogger mounted in an open field on the property $20 \mathrm{~m}$ north of the cave. Data from this logger were post-processed to convert tip rates (calibrated as 0.02 $\mathrm{mm} /$ tip) to daily $\mathrm{cm} /$ day values. Because this gauge was deployed in late June 2008, rainfall rates between late March (when the study began) and the deployment date were determined using daily observations archived by the National Weather Service Precipitation Analysis database (USGS Water Resources Water-Data Support Team, 2010; National Weather Service, 2010).

Cross-correlograms were used to determine the relationship between water-level in the cave and the river. They were also used to analyze the degree to which water-levels at both sites respond to rainfall. All cross-correlation analyses were performed using R version 2.10.1 (R Development Core Team, 2009).

\section{Cave $\mathrm{CO}_{2}: \delta^{13} \mathrm{C}$, concentration, and production rates}

Using a mask to prevent contamination by human respiration, cave-air samples for seasonal analyses of $\delta^{13} \mathrm{C}_{\mathrm{CO} 2}$ and $\mathrm{CO}_{2}$ concentration were collected from the Tangerine and Catfish entrances and their nearby passages (and when accessible, the Bat Wing and The Deep), the surface, and on the hardwood forest floor. Replicate samples were collected using 12-mL septum-capped vials preflushed with He (Fig. 3; Knohl et al., 2004) and obtained by opening the vials and leaving them to equilibrate for a period of 30 minutes. Vials were then capped and wrapped in Parafilm to prevent leakage, and transported in a cooler chilled to approximately $25^{\circ} \mathrm{C}$ to USF for analysis. Measurements of $\delta{ }^{13} \mathrm{C}_{\mathrm{CO} 2}$ were conducted using a Delta $\mathrm{V}$ gas-source isotope ratio mass spectrometer (IRMS) coupled to a Gasbench II peripheral following the methods of Tu et al. (2001). $\mathrm{CO}_{2}$ concentration of each sample was determined by gas chromatography (GC) using the GC column built into the Gasbench II. The peak area of mass 44 for the first of 10 replicate peaks was used and standardized with a mixture of $\mathrm{CO}_{2}$ in $\mathrm{He}$ with a concentration of $\sim 3000$ ppm. Two replicate values were averaged to obtain an Studia UBB Geologia, 2012, 57 (1), 53 - 61 
overall value for each site. In July 2008, freshly deposited guano was also collected from the Bat Wing to document whether $\mathrm{CO}_{2}$ respired from heterotrophic bacteria contributed to the atmosphere of the Bat Wing. Four replicate samples using a single guano pellet each were placed in the abovementioned septum-capped vials and flushed with $\mathrm{CO}_{2}$-free air to remove ambient $\mathrm{CO}_{2}$. Carbon dioxide production from the guano occurred over the time the samples (including cave atmosphere samples) were held for analysis and during the course of analysis prior to individual sampling by the IRMS (approximately 46 hours, total).

To estimate $\mathrm{CO}_{2}$ production rates from cave substrates as indicative of bacterial respiration within these materials, bench-top experimentation using fresh samples collected from dry and submerged wall rock, dry and submerged cave sediments, and surface soils were conducted to obtain $\delta^{13} \mathrm{C}$ and $\mathrm{CO}_{2}$ concentration values. Samples were collected in early December with the assumption that cooler conditions should lead to lower $\mathrm{CO}_{2}$ production rates such that rates measured in bench-top experimentation would yield minimum estimates. Substrates were placed in respiration chambers constructed using preserving jars with Swagelock ${ }^{\circledR}$ valves fitted with $2 \mathrm{~mm}$ septa affixed to the air-tight lids (Fig. 4). Ambient $\mathrm{CO}_{2}$ was flushed out of the jars using $\mathrm{CO}_{2}$-free air prior to sealing. Respiration chambers were allowed to incubate for a period of 23.8 days prior to $\mathrm{CO}_{2}$ sampling and measurement via IRMS analysis.
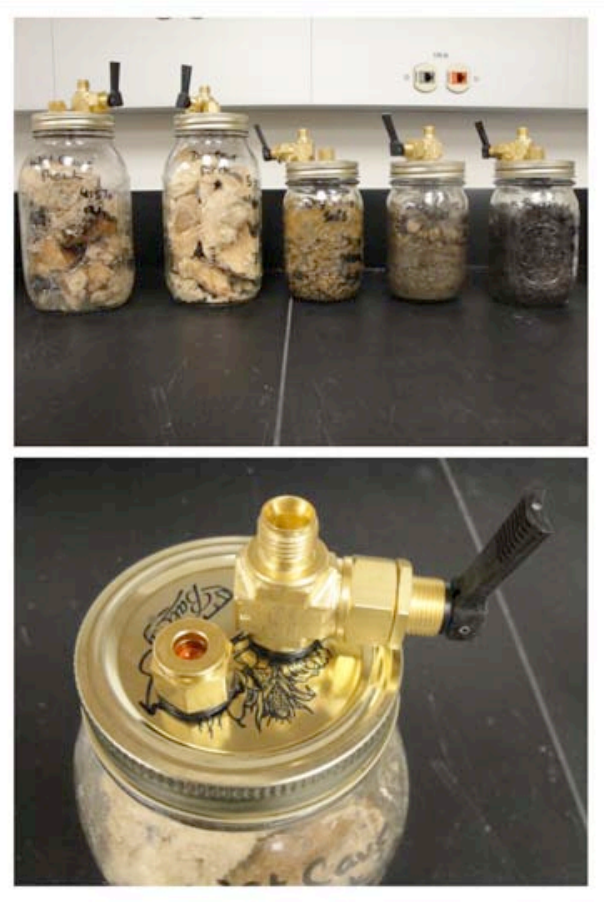

Fig. 4. $\mathrm{CO}_{2}$ respiration chambers. Bottom: close-up of Swagelock ${ }^{\mathbb{B}}$ valve and septa.

Carbon dioxide was collected from chambers using a gastight syringe to extract $2.5 \mathrm{~mL}$ of gas, which was then inserted into a $12-\mathrm{mL}$ septum-capped vial pre-flushed with He. Samples were analyzed using the above-mentioned methods to obtain $\delta{ }^{13} \mathrm{C}$ and $\mathrm{CO}_{2}$ concentration values. To estimate the $\mathrm{CO}_{2}$ flux/production rate for each chamber, substrate volume was calculated by filling the chambers to their headspace with a known volume of water (in $\mathrm{mL}$, after IRMS analysis) and subtracting that value from the total volume of the chamber. Using the calculated substrate volume, $\mathrm{CO}_{2}$ production was calculated per $\mathrm{m}^{3}$ over the total incubation time using the Ideal Gas Law. Standard pressure and a lab temperature of $295.7^{\circ} \mathrm{K}$ were used to calculate a 24.26 L volume occupied by one mole of gas, or $24.26 \mathrm{~mL}$ occupied by $1 \mathrm{mmol}$ of gas. Using this volume, the gas concentration at the same pressure and temperature conditions was calculated as $0.04 \mathrm{mmol} / \mathrm{mL}\left(C_{g}\right)$. This value was then used to convert the concentration of $\mathrm{CO}_{2}$ in $\mu \mathrm{L} / \mathrm{L}$ (ppmV) in each septum-capped sampling vial to mmol $\mathrm{CO}_{2}$, representing the amount of $\mathrm{CO}_{2}$ in the gas sample in the vial. This amount was calculated using Eq. 1, where $V_{c}$ is equal to the volume of the container in $\mathrm{mL}$ (in this case, the $12 \mathrm{~mL}$ vial):

$\left(\frac{\mu \mathrm{L}}{\mathrm{L}} \mathrm{CO}_{2} \times \frac{1 \mathrm{~L}}{1000 \mathrm{~mL}} \times \frac{1 \mathrm{~mL}}{1000 \mu \mathrm{L}}\right) \times V_{c} \mathrm{~mL} \times C_{g} \mathrm{mmol} / \mathrm{mL}=\mathrm{mmolCO}_{2} \quad$ Eq. 1

That value was converted back to $\mu \mathrm{L} / \mathrm{L}$ using the reverse of the above equation and assuming the $2.5 \mathrm{~mL}$ volume of the gas-tight syringe as $V_{c}$ to represent the concentration sampled from the each respiration chamber. To calculate the $\mathrm{mmol} / \mathrm{mL}$ concentration of $\mathrm{CO}_{2}$ in each respiration chamber, the $\mu \mathrm{L} / \mathrm{L}$ concentration previously calculated was converted assuming the void space volume of each chamber as $V_{c}$. Finally, the $\mathrm{CO}_{2}$ production rate in $\mu \mathrm{mol} \mathrm{m} \mathrm{m}^{-3} \mathrm{~s}^{-1}$ was calculated using Eq. 2, where $V_{s}$ is equal to the volume of the substrate in $\mathrm{m}^{3}$, and $t$ is equal to the total incubation time, in seconds:

$$
\frac{\mathrm{mmol} \mathrm{CO}_{2} \times \frac{1000 \mu \mathrm{mol}}{\mathrm{mmol}}}{V_{s} \mathrm{~m}^{3}} / t \mathrm{sec}=\mu \mathrm{molm}^{-3} \mathrm{~s}^{-1}
$$

It should be noted that the abovementioned methods utilized for $\mathrm{CO}_{2}$ sample collection are not biologically sterile and do not preclude the possibility of contamination by microbial species not endemic to the cave; however, these methods are commonly used in ecological studies to determine the lability of substrates available to microbes as energy by tracing the flow carbon (see Soloman and Cerling, 1987; Ehleringer et al., 2000; Šantrůčková, et al., 2000; Chen et al., 2002). Values of $\delta^{13} \mathrm{C}$ in particular are valuable indicators of the source of carbon in various substrates, and when combined with $\mathrm{CO}_{2}$ concentration and respiration rate data, can provide good estimates of carbon flux patterns and rates in a given environment.

\section{RESULTS AND DISCUSSION}

Temperature, water-level, rainfall, and $\mathrm{CO}_{2}$ data are each discussed below. During a flood event in July 2009, the two dataloggers recording air and water temperature in The Deep were lost, restricting the dataset for that site.

\section{Cave and surface temperature}

Data collected from cave- and surface-air and water temperature dataloggers were smoothed using a running average and plotted in Figure 5. Diurnal fluctuations in air temperatures were also plotted in Figure 5. Long-term cave-air temperatures show strong seasonal trends, even in The Deep, one of the more remote passages farthest from an entrance. At the same time, cave-air temperatures were slightly cooler than surface temperatures during the summer and slightly warmer in the winter. Even so, long-term caveand surface-air temperature differences were typically less than $2{ }^{\circ} \mathrm{C}$, illustrating the openness of the cave and indicating the degree of exchange between cave- and surface-air. A temperature 
inversion at The Deep occurred during December 2008 that does not appear at the remaining sites. While it could be assumed that a localized area of increased temperature is indicative of temporary animal habitation, the duration of this event coincided with bi-weekly geochemical sampling trips during which no animal traces were observed. The cause of this inversion is therefore unknown.

An example of daily air temperature variation from July 1 to July 5, 2008 illustrate a diurnal variation in cave temperature that varies from approximately 0.5 to $1^{\circ} \mathrm{C}$ (Fig. 5). Not surprisingly, variations at the Catfish Entrance are more pronounced than The Deep. This suggests that though muted, cave-air temperatures do respond simultaneously to temperature changes at the surface.
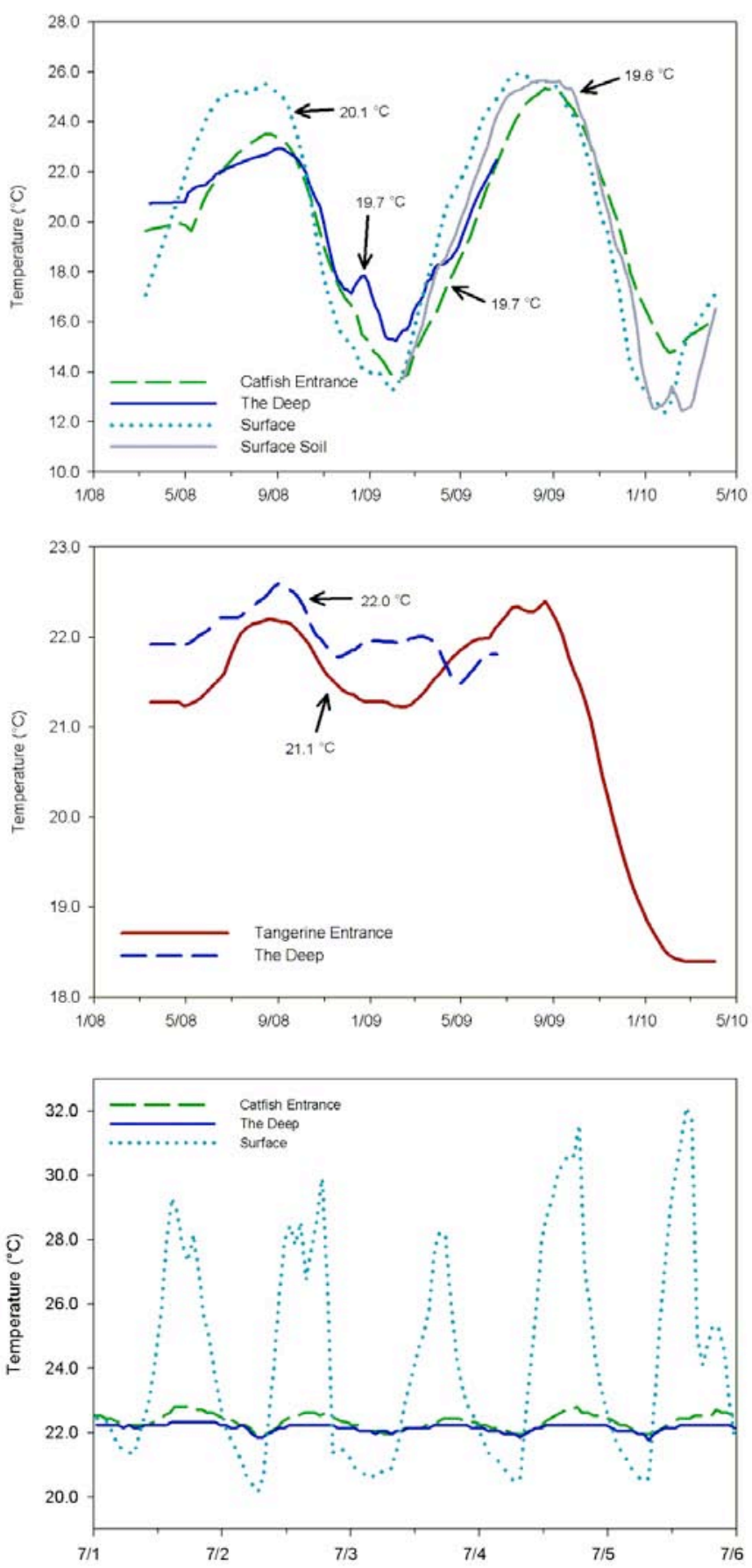

Fig. 5. Air and water temperature profiles at Thornton's Cave. Top: long-term air temperatures, March 2008 to April 2010; Middle: long-term water temperatures, March 2008 to April 2010; Bottom: example of diurnal fluctuations in air temperature, July 2009. Arrows indicate mean annual temperature for each site.
Water temperature at the Tangerine Entrance displays a seasonal trend that varied by approximately $1^{\circ} \mathrm{C}$ for most of the sampling cycle (Fig. 5). Tangerine Entrance temperature was $1^{\circ} \mathrm{C}$ or less cooler than The Deep, and may be due to the greater degree of exposure of waters at the Tangerine Entrance to the surface. Like the air, water temperatures at The Deep increased slightly in December 2008 but stayed warmer through the winter before decreasing slightly in the late spring of 2009. The cause for this is unknown as no such observation is seen at the Tangerine Entrance. Just as enigmatic is the steady decrease of water temperature at the Tangerine Entrance beginning in late 2009 that appeared to level out at the end of the sampling cycle in early spring 2010. Water temperature throughout the dataset, including the negative excursion at the Tangerine Entrance, are representative of Floridan Aquifer temperature (Sprinkle, 1989) supporting the hypothesis that perennial water bodies in the cave intersect the aquifer, with water-levels varying more as a result of fluctuations in the water table than from direct surface runoff during rain events. Given this, and the hypothesis established through exploratory dive operations that the Tangerine Entrance acts as a spring, it is possible that cooler water upwelling from the aquifer occurred in late 2009 through early 2010, lowering the temperature at the Tangerine Entrance.

\section{Rainfall and water-levels}

Rainfall rates and changes in water-level at Thornton's Cave and the Withlacoochee River are illustrated in Fig. 6.

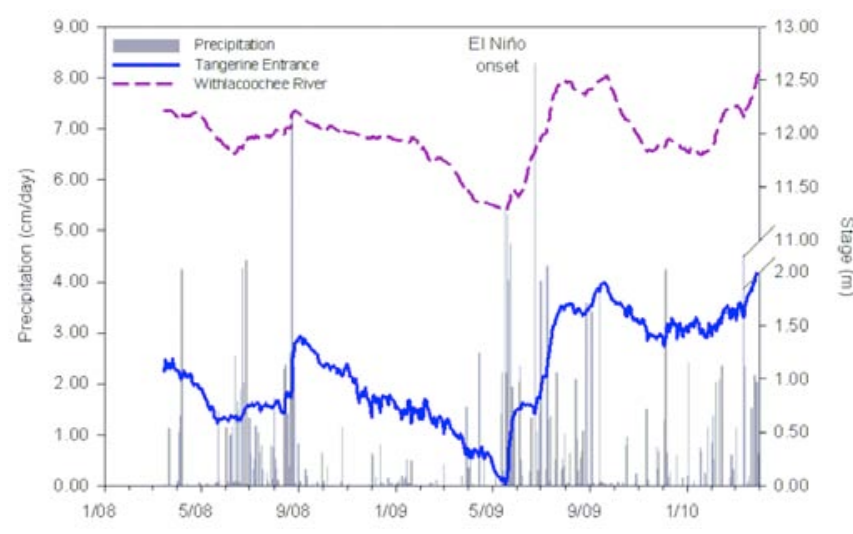

Fig. 6. Rainfall and stage data for Tangerine Entrance and Withlacoochee River. Data for Tangerine Entrance should be interpreted as trends rather than actual stage due to uneven depths attributed by variations in cave floor topography and presence of vertical passages.

Visual comparisons of wet- and dry-season water-levels at sites sampled in this study are illustrated in Figures 7 and 8. Overall, rainfall data are indicative Florida's wet summer/fall and dry winter/spring climate, particularly in 2008. The passage of Tropical Storm Fay between August 21 and 22 brought the highest rainfall amount for the year, with the remainder of rainfall events driven by afternoon/evening convection systems in the summer/fall and frontal systems in the winter and early spring. The onset of El Niño in 2009 reduced tropical storm and hurricane activity but maintained rainfall rates through the summer due to frontal and local convection systems. Most notably, the El Niño event contributed to increased rainfall activity through winter 2009/2010, a stark contrast to the previous year. These conditions persisted through the spring of 2010 when this study concluded. 


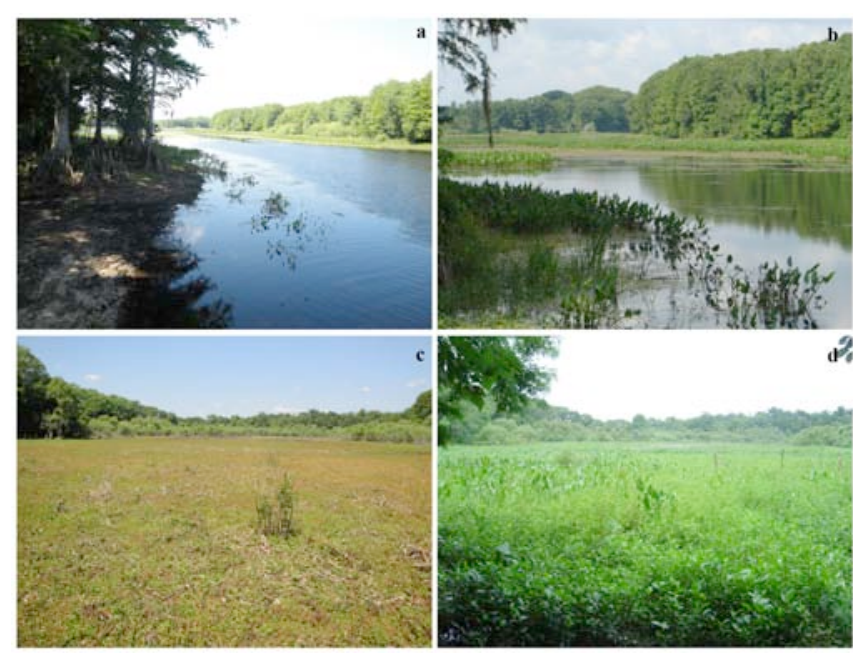

Fig. 7. Seasonal images of Withlacoochee River and Thornton's Slough: a) Withlacoochee River, dry season (looking south); b) Withlacoochee River, wet season (same vantage); c) Thornton's Slough, dry season (looking west toward river; note dried aquatic vegetation amid grasses); d) Thornton's Slough, wet season (same vantage).
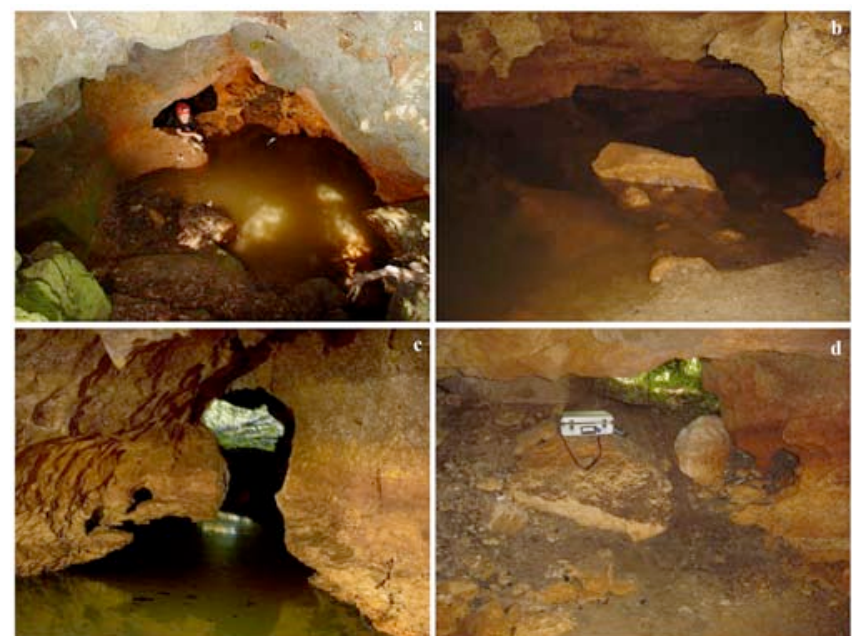

Fig. 8. Thornton's Cave entrances and passages: a) Tangerine Entrance (pool depth exceeds $30 \mathrm{~m}$ at right); b) Catfish Entrance (passage to Bat Wing and The Deep on right); c) perennially flooded passage west of Tangerine Entrance; d) typical dry cave entrance and passage. Figures $8 a$ and $8 c$ courtesy of T. Turner and A. Palmer, respectively.

Water-levels at both Thornton's Cave and the Withlacoochee River largely mirror one another and appear to respond rapidly to rainfall events (Figs. 6, 9). Water-levels at both locations were on the decline from the start of the study to June 2008 when they began to rebound with the onset of the wet season, particularly with the passage of Tropical Storm Fay in late August. From August onward, water-levels decreased steadily through the following winter and spring, reaching their lowest points in mid-May 2009 before rising dramatically with the onset of frequent and heavy rain events occurring through the summer. The rapid increase in intense rainfall eventually caused Thornton's Slough (fed by the Withlacoochee River) to flood into the cave through the entrance at Thornton's Spring in early July 2009 (Fig. 10), with water observably flowing through passages to the Catfish Entrance and The Deep and to the Tangerine Entrance until early August. Continuous rainfall through winter 2009/2010 maintained water-levels much higher than the previous year and in late March 2010 such that Thornton's Slough once again back-flooded into the cave along the same flow paths. This flooding continued through the end of this study in early April.
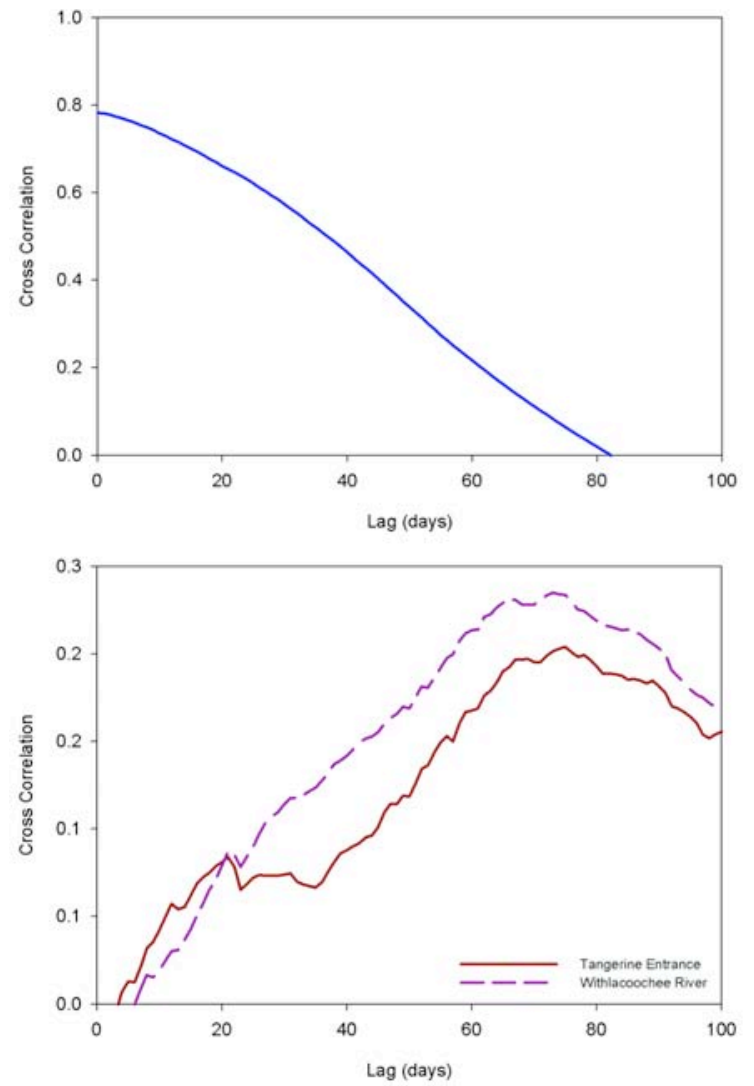

Fig. 9. Cross-correlograms of water-level and rainfall data at the Tangerine Entrance and the Withlacoochee River. Top: Cross-correlation of water-levels at each site. Bottom: Cross-correlation of rainfall and water-level at each site.

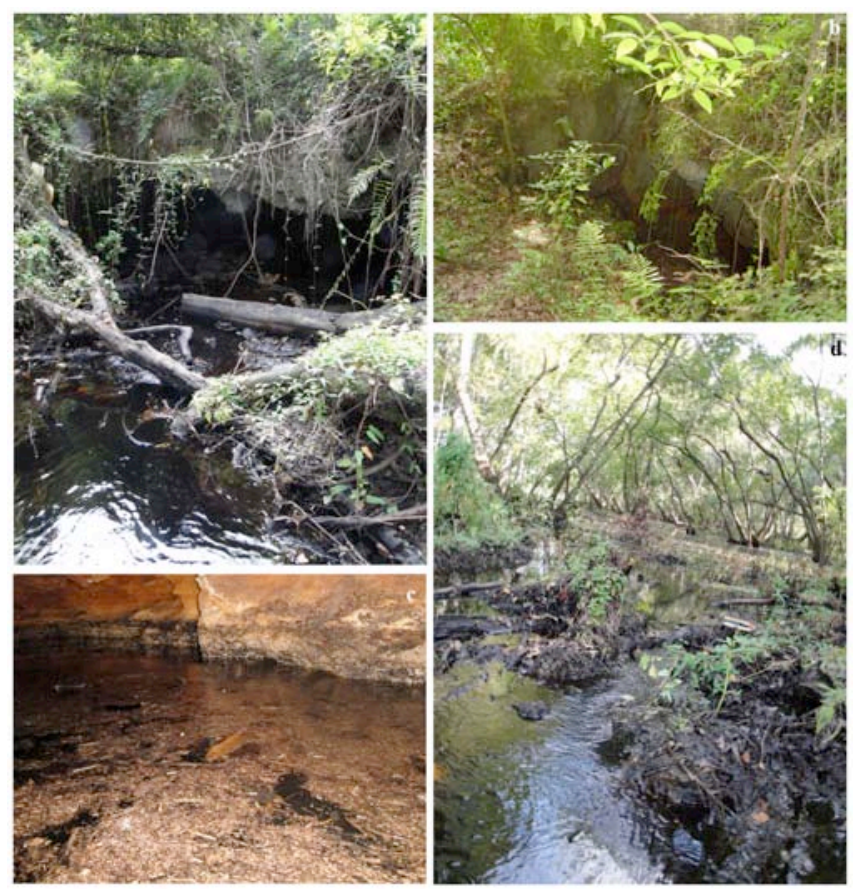

Fig. 10. Summer 2009 flood images: a) outflow from Thornton's Spring Entrance; b) Thornton's Spring Entrance (dry season comparison); c) flooded Catfish Entrance including surface debris (connection to The Deep \& Bat Wing submerged along wall); d) flooded cypress hammock flowing to slough (view from Thornton's Spring west toward slough).

Steady rainfall and elevated water-levels from summer 2009 to spring 2010 coincide with the gradual decrease in water temperature at the Tangerine Entrance and may help explain this phenomenon. The continual recharge to the Floridan Aquifer over this time period may have gradually 
flushed cooler water from deeper in the aquifer upward toward the surface where it discharged at springs. Deeper waters should be cooler than waters at the Tangerine Entrance, which are influenced by surface air temperatures and direct exposure to sunlight (Fig. 8a). This steady increase in upward flow from the aquifer would explain the steady decrease in water temperature at the Tangerine Entrance.

\section{Cave-air $\mathrm{CO}_{2}$}

Seasonal cave-air $\mathrm{CO}_{2}$ sampling from 2008 to 2010 show that $\mathrm{CO}_{2}$ concentrations reach their peak in the late summer and fall, while at the same time, $\delta{ }^{13} \mathrm{C}_{\mathrm{CO} 2}$ values are at their lowest. These values range from $\sim 450 \mathrm{ppm}$ and $\sim 11 \%$ at the entrances to $\sim 1230 \mathrm{ppm}$ and $-19 \%$ in more remote passages (Table 1).

Table 1. Summary of seasonal $\mathrm{CO}_{2} \delta^{13} \mathrm{C}$ and concentration variations, by site

\begin{tabular}{|c|c|c|c|c|c|c|c|c|c|c|}
\hline & \multicolumn{2}{|c|}{ July 08} & \multicolumn{2}{|c|}{ February 09} & \multicolumn{2}{|c|}{ June 09} & \multicolumn{2}{|c|}{ October 09} & \multicolumn{2}{|c|}{ December 2009} \\
\hline & $\begin{array}{c}\delta^{13} \mathrm{C}_{\mathrm{CO} 2} \\
(\% \mathrm{o})\end{array}$ & $\begin{array}{l}\text { Conc. } \\
\text { (ppm) }\end{array}$ & $\begin{array}{c}\delta^{13} \mathbf{C}_{\mathrm{CO} 2} \\
(\% \mathrm{o})\end{array}$ & $\begin{array}{l}\text { Conc. } \\
\text { (ppm) }\end{array}$ & $\begin{array}{c}\delta^{13} \mathbf{C}_{\mathrm{CO} 2} \\
(\%)\end{array}$ & $\begin{array}{l}\text { Conc. } \\
\text { (ppm) }\end{array}$ & $\begin{array}{c}\delta^{13} \mathbf{C}_{\mathrm{CO} 2} \\
(\%)\end{array}$ & $\begin{array}{l}\text { Conc. } \\
\text { (ppm) }\end{array}$ & $\begin{array}{c}\delta^{13} \mathbf{C}_{\mathrm{CO} 2} \\
(\% 0)\end{array}$ & $\begin{array}{l}\text { Conc. } \\
\text { (ppm) }\end{array}$ \\
\hline Tangerine Entrance & -10.5 & 466 & -9.60 & 409 & -11.41 & 440 & -13.78 & 515 & -9.05 & 431 \\
\hline Tangerine Ent. Passage & -12.3 & 525 & -9.62 & 411 & -11.02 & 437 & -15.73 & 620 & -12.74 & 611 \\
\hline Catfish Ent & -15.8 & 805 & -11.39 & 470 & -10.97 & 419 & -17.01 & 727 & -9.52 & 445 \\
\hline Catfish Ent. Passage & -12.6 & 534 & -9.92 & 417 & -11.10 & 431 & & & & \\
\hline Bat Wing & -19.4 & 1234 & -11.39 & 481 & -18.96 & 1232 & & & & \\
\hline Forest Floor & -8.8 & 391 & -12.09 & 488 & -14.74 & 545 & -18.16 & 762 & -8.81 & 417 \\
\hline Surface Atmosphere & -8.6 & 381 & -9.39 & 405 & -9.59 & 384 & -9.72 & 383 & -8.26 & 397 \\
\hline Guano & -22.8 & 1056 & & & & & & & & \\
\hline
\end{tabular}

During these months, $\mathrm{CO}_{2}$ concentrations and $\delta{ }^{13} \mathrm{C}_{\mathrm{CO} 2}$ values at the Catfish Entrance are typically 200-300 ppm higher and 5\%o lower, respectively, than that of the Tangerine Entrance and likely result from the respiration of the breeding bat colony in the adjacent Bat Wing where $\mathrm{CO}_{2}$ concentrations were highest $(\sim 1230 \mathrm{ppm})$ and $\delta{ }^{13} \mathrm{C}_{\mathrm{CO} 2}$ values were lowest $(\sim-19 \%$; Fig. 11). In addition, decomposition of thick deposits of guano by microorganisms is likely providing an additional source of $\mathrm{CO}_{2}$ to the Bat Wing, evidenced by $\mathrm{CO}_{2}$ produced from four replicate samples of freshly collected guano. During the cooler months, $\mathrm{CO}_{2}$ concentrations remain higher and $\delta^{13} \mathrm{C}_{\mathrm{CO} 2}$ values lower in the more remote passages but typically stay below $500 \mathrm{ppm}$ and above $-12 \%$, respectively. Regardless of season, cave $\mathrm{CO}_{2}$ concentrations were always higher and more ${ }^{13} \mathrm{C}$-depleted than surface $\mathrm{CO}_{2}$. These data suggest that despite ample ventilation to the surface, as suggested by temperature profiles, biogenic $\mathrm{CO}_{2}$ accumulates in the cave, particularly during the summer months. This is evidence that biotic activity from microbial respiration and/or that of macrobiota is greater during the warmer, wetter season and contributes a significant amount of $\mathrm{CO}_{2}$ produced in situ to the cave system.

While macroorganisms such as bats undoubtedly provide an important source of $\mathrm{CO}_{2}$ in the summer, the microbial production of $\mathrm{CO}_{2}$ within cave substrates is evidenced by low $\delta{ }^{13} \mathrm{C}_{\mathrm{CO} 2}$ values shown in Table 2 , with production rates ranging from 0.10 to $0.23 \mu \mathrm{mol} \mathrm{m} \mathrm{m}^{-3} \mathrm{~s}^{-1}$ in the cave. Production rates calculated from surface soils were the highest $\left(0.33 \mu \mathrm{mol} \mathrm{m} \mathrm{m}^{-3} \mathrm{~s}^{-1}\right)$ with a $\delta^{13} \mathrm{C}_{\mathrm{CO} 2}$ value of $-23.1 \%$, characteristic of soils from $\mathrm{C}_{3}$-dominated vegetative environments (Ehrlinger and Cerling, 2000). Within the cave, production rates seemed to be driven first by substrate type and secondarily by moisture, as rates were first highest in cave wall rock and then in wet samples. This is an indicator that microorganisms may be thriving on dissolved organic carbon (DOC) leached through the rock by the infiltration of water from the soils above. If this is the case, respiration of $\mathrm{CO}_{2}$ may be higher in the summer months as organic activity increases. Interestingly, $\delta^{13} \mathrm{C}_{\mathrm{CO} 2}$ values observed from $\mathrm{CO}_{2}$ produced in dry cave rock are at least $5 \%$ more enriched in ${ }^{13} \mathrm{C}$ than the remaining samples, which might suggest that the pore spaces of dry rock may contain relatively higher volumes of surface $\mathrm{CO}_{2}$ with the characteristic $\delta{ }^{13} \mathrm{C}_{\mathrm{CO} 2}$ value closer to $-8 \%$ (Craig, 1953). Alternatively, this $\mathrm{CO}_{2}$ could be derived from inorganic sources such as abiotic precipitation of $\mathrm{CaCO}_{3}$.

Table 2. Results from bench-top $\mathrm{CO}_{2}$ production experiments.

\begin{tabular}{|l|c|c|}
\hline & $\begin{array}{c}\boldsymbol{\delta}^{\mathbf{1 3}} \mathbf{C} \\
(\%)\end{array}$ & $\begin{array}{c}\mathbf{C O}_{2} \text { production, by particle } \\
\text { volume (excl. pore space) } \\
\left(\mu \mathrm{mol} \mathrm{m}^{-3} \mathrm{~s}^{-1}\right)\end{array}$ \\
\hline Wet cave rock & -18.5 & 0.23 \\
\hline Dry cave rock & -13.2 & 0.18 \\
\hline Wet cave sediment & -21.1 & 0.15 \\
\hline Dry cave sediment & -20.3 & 0.10 \\
\hline Surface soils & -23.1 & 0.33 \\
\hline
\end{tabular}

Heterotrophic microbial production of $\mathrm{CO}_{2}$ from rock has been documented as far back as the early 1900s when Paine et al. (1933) characterized and enumerated bacteria sampled from various building stones (typically limestones and marbles) and measured $\mathrm{CO}_{2}$ respired from them in an attempt to determine the microbial contribution to the degradation of these stones. The combined works of Paine et al. (1933) and Schwabe et al. (2008) show that bacterial counts are highest in the first $2-5 \mathrm{~cm}$ depth from the surface, likely due to limitations in oxygen and nutrient availability. If we were to assume all the $\mathrm{CO}_{2}$ produced in these experiments occurs in the outermost $5 \mathrm{~cm}$ of the rock and sediment, then we can compare production rates measured in this study to production rates calculated from soil $\mathrm{CO}_{2}$ flux rates published in other studies. Common $\mathrm{CO}_{2}$ flux rates measured in tropical forest, grassland and montane soils range from $1 \mu \mathrm{mol} \mathrm{m} \mathrm{m}^{-2}$ to $8 \mu \mathrm{mol} \mathrm{m}^{-2} \mathrm{~s}^{-1}$ (Janssens et al., 1998; Chen et al., 2002; Kao and Chang, 2009; Wei et al., 2010). Assuming this $\mathrm{CO}_{2}$ is produced in the upper $5 \mathrm{~cm}$ of the soil column (i.e., multiplying the flux rate by a factor of 0.05 ) yields $\mathrm{CO}_{2}$ production rates varying from $20 \mu \mathrm{mol}$ $\mathrm{m}^{-2} \mathrm{~s}^{-1}$ to $160 \mu \mathrm{mol} \mathrm{m} \mathrm{m}^{-2} \mathrm{~s}^{-1}$, well above the production rates measured for Thornton's Cave substrates. While it might be expected that $\mathrm{CO}_{2}$ production rates in the cave would be lower than that of most surface soils, this does not account for the low production rate calculated for the soils collected from the forest overlying the cave in this study. At the same time, the $\mathrm{CO}_{2}$ production rates measured in this study are within the lower range of modeled production rates from 
soils in a montane region in Utah, USA (Solomon and Cerling, 1987). We should therefore interpret $\mathrm{CO}_{2}$ production rates calculated from published soil $\mathrm{CO}_{2}$ flux rates with caution by acknowledging the differences in bacterial community distribution between the pore spaces of rocks and that of soils, and their effects on the depth to which $\mathrm{CO}_{2}$ is produced. Regardless, these bench-top studies document that $\mathrm{CO}_{2}$ production of heterotrophic microorganisms in soils and rock do contribute to atmospheric $\mathrm{CO}_{2}$ in the cave and should be assessed under field conditions to establish more reliable rates of production and efflux. They also implicate microorganisms as potential factors influencing dissolution by contributing to $\mathrm{CO}_{2}$ that can acidify vadose water in both the rock and sediment pore spaces, as well as acidify wall condensate as $\mathrm{CO}_{2}$ degasses from these substrates to the cave atmosphere.
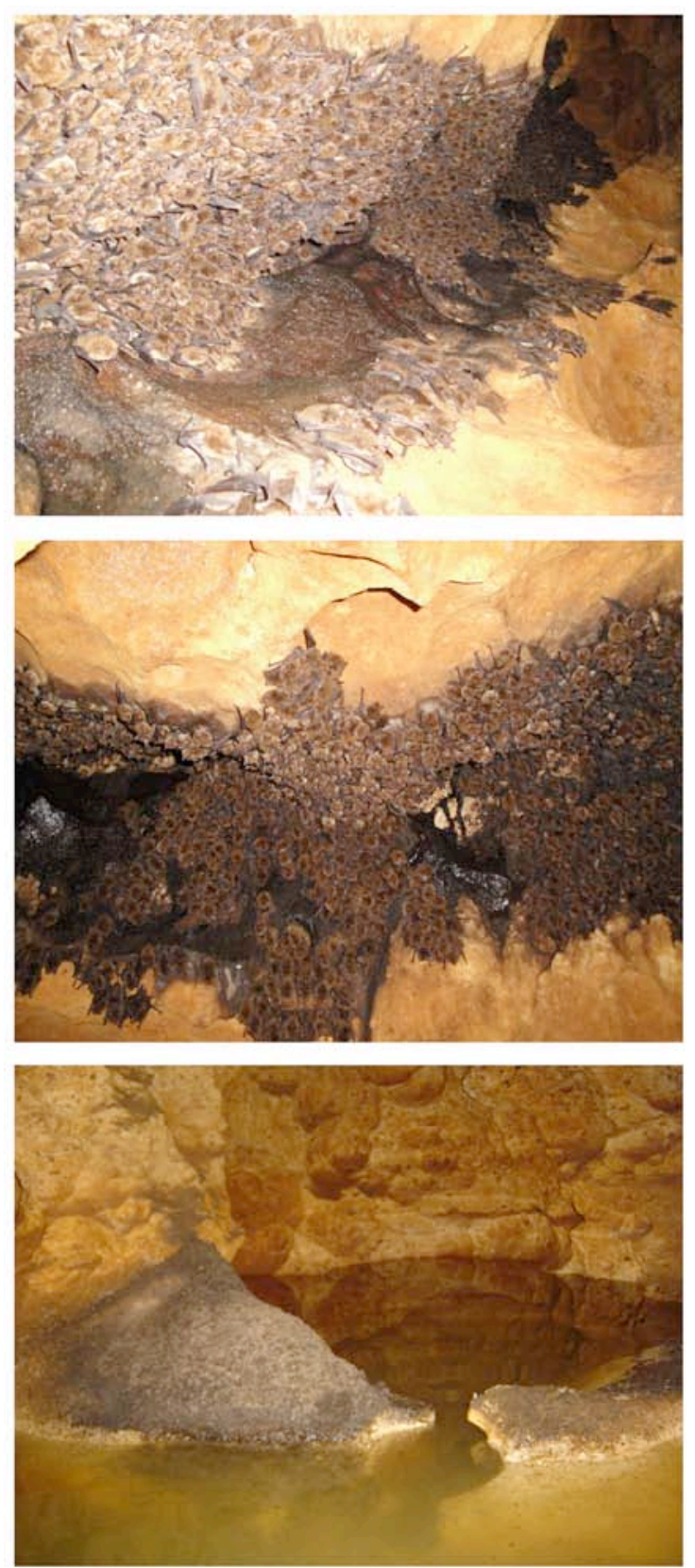

Fig. 11. Bat Wing summer maternity roosting colony. Top - Middle: roosting colonies (individuals $\sim 5-8 \mathrm{~cm}$ in length); Bottom: guano deposits on exposed surfaces below the colony.

Note: Limited photos taken under guidance of Jeff Gore, scientific advisor for the Florida Bat Conservancy. As of January 2010, white-nose syndrome (WNS) caused by the fungal species Geomyces destructans, not reported in Florida bat populations.

\section{SUMMARY AND CONCLUSIONS}

Climate, hydrologic and $\mathrm{CO}_{2}$ data collected from Thornton's Cave exhibits a strong degree of connectivity between surface and subsurface processes, which is to be expected given the cave's proximity and openness to the surface. Long-term trends in temperature data at the cave's entrances and more remote passages are not dissimilar to surface temperatures, both in actual values and seasonality. Diurnal variation in cave temperatures occur on a shorter time-scale at both the entrances and remote passages as well, though the temperature range is much smaller than that observed at the surface. These data support that the cave responds simultaneously to both long- and short-term temperature flux at the surface. Water temperatures at the Tangerine Entrance and The Deep are more consistent with a mild seasonal trend and are probably regulated more so by the Floridan Aquifer than air temperature. At the same time, water-levels at the cave are well-correlated to both rainfall and variations in water-level at the Withlacoochee River. Water-levels at the cave respond rapidly to rainfall at the surface, owing to the high permeability and transmissivity of the Ocala Limestone and to a lesser degree, runoff from the surface.

Seasonal surveys of atmospheric $\mathrm{CO}_{2}$ at the cave suggest that during the wet season, $\mathrm{CO}_{2}$ concentrations both increase and are more influenced by biotic sources compared to the dry season when $\mathrm{CO}_{2}$ concentrations are lower and more similar to surface atmospheric values. The marked accumulation of $\mathrm{CO}_{2}$ in the cave atmosphere during the wet season combined with its lower $\delta^{13} \mathrm{C}$ values is evidence that cave $\mathrm{CO}_{2}$ is produced in situ at a rapid enough rate to allow for accumulation despite the cave's ample ventilation to the surface. Though a significant portion of this $\mathrm{CO}_{2}$ is likely sourced from the breeding bat colony occupying the Bat Wing during the summer (as well as degassing from guano deposits), $\mathrm{CO}_{2}$ may also be degassed from cave wall rock and floor sediment, particularly in the wetter regions of the cave. This $\mathrm{CO}_{2}$ is sourced from the respiration of microorganisms living in the sediment and pore spaces of the rock as they break down organic matter. This is a strong indicator that microorganisms could be contributing to the dissolution of the cave by providing ample $\mathrm{CO}_{2}$ to diffuse and dissolve into water to produce $\mathrm{H}_{2} \mathrm{CO}_{3}$, a common corrosion agent in many limestone systems.

Acknowledgements. The author would like to thank Peter J. Harries, Jonathan G. Wynn, Bogdan P. Onac, H.L. Vacher (University of South Florida) and Diana E. Northup (University of New Mexico) for their valuable feedback and insight in the preparation of this manuscript. She would also wish to thank Ray and Sharon Thornton for graciously allowing the use of their cave and property for this research; Lee Florea (Ball State University), Robert Brooks \& Tom Turner (Florida Speleological Survey), and Dave DeWitt (Southwest Florida Water Management District) for their field assistance and discussion; and Zac Atlas and Hanna Endale (University of South Florida) for their laboratory assistance. This research was supported by funding from the Geological Society of America, the Sigma Xi Scientific Research Society, and the National Speleological Society. 


\section{R E F E R E N C E S}

Budd, D.A., Vacher, H.L. 2004, Matrix permeability of the confined Floridan Aquifer, Florida, USA. Hydrogeology Journal, 12 (5): 531-549. http://dx.doi.org/10.1007/s10040-004-0341-5

Chen, X., Eamus, D. \& Hutley, L.B. 2002, Seasonal patterns of soil carbon dioxide efflux from a wet-dry tropical savanna of northern Australia. Australian Journal of Botany, 50: 43-51. http://dx.doi.org/10.1071/BT01049

Cooke, C.W. 1931, Seven coastal terraces in the southeastern states. Washington Academy of Sciences Journal, 21: 503-513.

Craig, H. 1953, The geochemistry of stable carbon isotopes. Geochimica et Cosmochimica Acta, 3: 53-92. http://dx.doi.org/10.1016/0016-7037(53)90001-5

Ehleringer, J.R., Buchmann, N. \& Flanagan, L.B. 2000, Carbon isotope ratios in belowground carbon cycle processes. Ecological Applications, 10 (2): 412-422. http://dx.doi.org/10.1890/1051-0761(2000)010[0412:CIRIBC]2.0.CO;2

Florea, L.J., Noe-Stinson, C.L., Brewer, J., Fowler, R., Kearns, B.J. \& Greco, A.M. 2011, Iron oxide and calcite associated with Leptothrix sp. biofilms within an estavelle in the upper Floridan aquifer. International Journal of Speleology, 40 (2): 205-219. http://dx.doi.org/10.5038/1827-806X.40.2.12

Florea, L.J., Gentry, C.L., Onac, B.P., Soto, L. \& Turner, T. 2006, Thornton's Cave (Sumter County Bat Cave). USF Karst Research Group, Tampa, FL.

Florea, L.J., Vacher, H.L. 2006, Springflow hydrographs: eogenetic vs. telogenetic karst. Ground Water, 44 (3): 352-361. http://dx.doi.org/10.1111/j.1745-6584.2005.00158.x

Florea, L.J., Vacher, H.L., Donahue, B. \& Naar, D. 2007, Quaternary cave levels in peninsular Florida. Quaternary Science Reviews, 26: 1344-1361.

http://dx.doi.org/10.1016/j.quascirev.2007.02.011

Janssens, I.A., Têtè Barigah, S. \& Ceulemans, R. 1998, Soil $\mathrm{CO}_{2}$ efflux rates in different tropical vegetation types in French Guiana. Annals of Forest Science, 55: 671-680. http://dx.doi.org/10.1051/forest:19980603

Kao, W.-Y., Chang, K.-W. 2009, Soil $\mathrm{CO}_{2}$ efflux from a mountainous forest-grassland ecosystem in central Taiwan. Botanical Studies, 50: 337-342.

Knohl, A.W., R.A.; Geilmann, H. \& Brand, W.A. 2004, Kel-F ${ }^{\mathrm{TM}}$ discs improve storage time of canopy air samples in $10-\mathrm{mL}$ vials for $\mathrm{CO}_{2}-\delta^{13} \mathrm{C}$ analysis. Rapid Communications in Mass Spectrometry, 18: 1663-1665. http://dx.doi.org/10.1002/rcm.1528

Lane, E. 1986, Karst in Florida. Florida Geological Survey, Tallahassee, FL, $100 \mathrm{p}$.

McGee, D.K. 2010, Microbial influences on karst dissolution: the geochemical perspective, with a chapter on assessment of the Spreadsheets Across the Curriculum project. Unpublished PhD thesis (\# 701908295), Department of Geology, University of South Florida, USA, $326 \mathrm{p}$.

Miller, J.A. 1986. Hydrogeologic framework of the Floridan Aquifer System in Florida and in parts of Georgia, Alabama, and South Carolina: Regional Aquifer-System Analysis. U.S.G.S., Washington, D.C., 91 p.

National Weather Service Advanced Hydrologic Prediction Service 2010, http://water.weather.gov/precip (accessed 2008-2010).
Paine, S.G., Lingood, F.V., Schimmer, F. \& Thrupp, T.C. 1933, The relationship of microorganisms to the decay of stone. Philosophical Transactions of the Royal Society of London, 222B: 97-127. http://dx.doi.org/10.1098/rstb.1932.0013

Palmer, A.N. 2007, Cave Geology. Cave Books, Trenton, New Jersey, $454 \mathrm{p}$.

Randazzo, A.F., Jones, D.S. (Eds.) 1997, The Geology of Florida. University Press of Florida, Gainesville, Florida, $327 \mathrm{p}$.

Ryder, P.D. 1985, Hydrology of the Floridan Aquifer System in West-Central Florida: Regional AquiferSystem Analysis, U.S. Geological Survey, Washington, D.C., 63 p.

Šantrůčková, H., Lloyd, M.I. \& Lloyd, J. 2000, Microbial processes and carbon-isotope fractionation in tropical and temperate grassland soils. Functional Ecology, 14 (1): 108-114. http://dx.doi.org/10.1046/j.1365-2435.2000.00402.x

Schwabe, S.J., Herbert, R.A. \& Carew, J.L. 2008, A hypothesis for biogenic cave formation: a study conducted in the Bahamas. In: Proceedings of the Thirteenth Symposium on the Geology of the Bahamas and Other Carbonate Regions (Park, L.E., Freile, D., Eds.), Gerace Research Centre, San Salvador, The Bahamas, p. 141-152.

Solomon, D.K., Cerling, T.E. 1987, The annual carbon dioxide cycle in a montane soil: observations, modeling, and implications for weathering. Water Resources Research, 23: 2257-2265. http://dx.doi.org/10.1029/WR023i012p02257

Sprinkle, C.L. 1989, Geochemistry of the Floridan Aquifer System in Florida and in Parts of Georgia, South Carolina, and Alabama: Regional Aquifer-System Analysis, U.S. Geological Survey, Washington, D.C., $105 \mathrm{p}$.

Stringfield, V.T., LeGrand, H.E. 1966, Hydrology of limestone terraces in the coastal plain of the southeastern United States, Geological Society of America, Denver, Colorado, $41 \mathrm{p}$.

USGS Water Resources Water-Data Support Team 2010, http://waterdata.usgs.gov/fl/nwis/uv/?site no $=02312598$ \&PARA meter $\mathrm{cd}=00065,00060$ (accessed 2008-2010).

Tu, K.P.B., Brooks, P.D. \& Dawson, T.E. 2001, Using septum-capped vials with continuous-flow isotope ratio mass spectrometric analysis of atmospheric $\mathrm{CO}_{2}$ for Keeling plot applications. Rapid Communications in Mass Spectrometry, 15: 952-956. http://dx.doi.org/10.1002/rcm.320

Wei, W., Shushi, P., Tao, W. \& Jingyun, F. 2010, Winter soil $\mathrm{CO}_{2}$ efflux and its contribution to annual soil respiration in different ecosystems of a forest-steppe ecotone, north China. Soil Biology \& Biogeochemistry, 42: 451-458. http://dx.doi.org/10.1016/j.soilbio.2009.11.028

Yon, J.W., Hendry, C.W. 1972, Suwannee Limestone in Hernando and Pasco counties, Florida; Part I, Florida Bureau of Geology Bulletin, 54, 42 p. 